\title{
Diversity and flight activity of aphid species as potential vectors of oilseed pumpkin viruses in Serbia
}

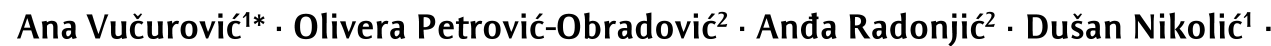 \\ Katarina Zečević ${ }^{1}$ Ivana Stanković1 · Branka Krstić1
}

${ }^{1}$ University of Belgrade, Faculty of Agriculture, Institute of Phytomedicine, Department of Phytopathology, Nemanjina 6, 11080 Belgrade, Serbia 2University of Belgrade, Faculty of Agriculture, Institute of Phytomedicine, Department of Entomology and Agricultural Zoology, Nemanjina 6, 11080 Belgrade, Serbia

\begin{abstract}
Summary: The fauna of aphids appearing on cucurbits, including oilseed pumpkin have been poorly investigated in Serbia. Yellow water traps were used to determine the diversity of aphid species visiting cucurbits in Serbia and to monitor their flight activity. During the years 2009 to 2011, a total of 1,447 specimens were collected and a total of 57 different aphid taxa were identified. In 2009, the highest total number of aphids were caught (755), followed by 203 and 489 aphids in 2010 and 2011, respectively. The most abundant species were Aphis fabae (15\%), Myizus persicae (13.4\%) and Acyrthosiphon pisum (11.7\%), followed by Anoecia corni (6.4\%) and Aphis gossypii (5.6\%). All of them, except A. corni, are reported as efficient vectors of cucurbit viruses. These five species represent $52.1 \%$ of all aphid species collected within this study. Out of 57 taxa found in oilseed pumpkin crops, 17 are known as vectors of ZYMV, 18 of WMV and 15 of CMV. Generally, 25 out of a total of 57 taxa are known as vectors of at least one of three viruses present in Serbia. From total of 1,447 specimens collected during three years of investigation, $917(63.4 \%)$ are vectors of at least one of three viruses. Individual oilseed pumpkin plants were frequently colonized by $A$. gossypii during all three years of investigation. Results of this study showed that Serbian oilseed pumpkin growing localities are grouped among medium to reach in aphidofauna, according to total Shannon-Weaver index values which varied from 1.8 to 2.8. The highest value of Shannon-Weaver (2.8) was recorded in the Bački Petrovac I locality in 2009, while the lowest Shannon-Weaver (1.8) was recorded in Kisač locality in 2010. The maximum values of Shanon-Weaver diversity index in almost all crops were recorded in the second week of investigation or in early stages of oilseed pumpkin growth when plants had 5-6 true leaves or were in flowering stage, when potential virus infection could lead to significant yield losses.

Key words: aphid diversity, aphid flight activity, Shannon-Weaver index diversity, oilseed pumpkin, yellow water trap, virus vectors
\end{abstract}

\section{Introduction}

Cucurbits are among the top 10 in economic importance among the vegetable crops of the world (Schaffer and Paris, 2003). Total cucurbit production in Serbia takes place on approximately 13,500 ha (Berenji, 2010; RZS, 2014; FAO, 2014). Over the last decades, an increase of cucurbit production in Serbia is noticed, especially of oilseed pumpkin (Cucurbita pepo L. var. styriaca) production (Berenji et al., 2004).

Plant viruses are the most important limitation to cucurbit production causing significant losses all over the world (Bananej et al., 2008). It is reported that more

Corresponding author:

ana.vucurovic@yahoo.com

Acknowledgments:

The study was supported by the Ministry of Education, Science and Technological Development of the Republic of Serbia (Project III 43001Agrobiodiversity and use of land in Serbia: an integrated assessment of biodiversity core group of arthropods and plants pathogens). than 50 well characterized viruses are known to naturally infect cucurbits (Kucharek \& Purcifull, 1997). Among them, aphid-borne viruses are considered economically the most important cucurbit pathogens worldwide (Provvidienti \& Schroeder, 1970; Lecoq et al., 2003; Bananej et al., 2008). On cucurbits in Serbia, five viruses have been identified: Zucchini yellow mosaic virus (ZYMV), Cucumber mosaic virus (CMV), Watermelon mosaic virus (WMV), Tomato spotted wilt virus (TSWV) (Vučurović et al., 2012), and Cucurbit aphid-borne yellows virus (CABYV) (Vučurović et al., 2011). ZYMV, CMV and WMV are the most frequent and widespread cucurbit viruses in Serbia and in some years, they can cause massive damage or total loss to cucurbit crops (Vučurović et al., 2012). These viruses are efficiently transmitted by aphids (Hemiptera, Sternorryhyncha, Aphididae).

Aphids attack cucurbits wherever they are grown, but only 10 aphid species are known as cucurbit colonizers (Blackman \& Eastop, 2006). Apart from causing direct feeding damage to cucurbits when their colonies develop, aphids are even more significant as vectors of viruses (Luis-Arteaga et al., 1998; Sevik \& 
Arli-Sokmen, 2003). Aphis gossypii Glover (melon aphid) is by far the most important of the direct pests, but Myzus persicae (Sulzer) (peach-potato aphid) and Aphis craccivora Koch (cowpea aphid) also attack cucurbits (Webb, 2007). In nature, CMV is transmitted by more than 80 aphid vector species in a non-persistent manner (Palukaitis \& García-Arenal, 2003). The most important vectors are Acyrthosiphon pisum (Haris), Aphis craccivora, Aphis fabae Scopoli, Aphis gossypii, Aphis glycines Matsumura, Aphis spiraecola Patch, Macrosiphum euphorbiae (Thomas), Myzus persicae, Nearctaphis bakeri (Cowen), Rhopalosiphum maidis (Fitch) and Therioaphis trifolii (Monell) (Palukaitis \& García-Arenal, 2003; Gildow et al., 2008). The green peach aphid, Myzus persicae, is one of the most efficient vectors for CMV (Hily et al., 2014). Also, most common and most studied CMV vector is Aphis gossipii (Palukaitis et al., 1992).

ZYMV is transmitted non-persistently by many colonizing and non-colonizing aphid species (Desbiez \& Lecoq, 1997). To date 26 aphid species have been reported as vectors of ZYMV: Aphis gossypii, Aphis craccivora, Aphis spiraecola, Aphis middletonii Thomas, Acyrthosiphon kondoi Shinji, Acyrthosiphon pisum, Lipaphis erysimi (Kaltebach), Macrosiphum euphorbiae, Myzus persicae, Uroleucon sp., Aphis craccae L., Aphis fabae, Aphis nerii Boyer de Fonscolombe., Aulacorthum solani (Kaltenbach), Brachycaudus cardui (L.), Brevicoryne brassicae (L.), Hyalopterus pruni complex, Hyperomyzus lactucae (L.), Macrosiphoniella sanborni (Gillette), Macrosiphum rosae (L.), Metopolophium dirhodum (Walker), Myzus cerasi (F.), Rhopalosiphum maidis, R. padi (L.), Semiaphis danci (F.), and Sipha maydis Passerini (Katis et al., 2006). The most efficient species of aphids in the transmission of ZYMV found to be $M$. persicae, $A$. gossypii and $A$. spiraecola (Castle et al., 1992; Provvidenti, 2000).

More than 40 aphid species have been reported to transmit WMV (Palukaitis et al., 1992). Out of the species known to transmit WMV, only A. gossypii colonizes the cucurbits (Perring et al., 1992).

Composition of aphid species and their role as colonizing or non-colonizing vectors in spreading the cucurbit viruses has not yet been investigated in Serbia. The aim of this study was to evaluate diversity of aphid species in oilseed pumpkin crops in Serbia and monitor

Table 1. Overview of localities where yellow water traps were installed

\begin{tabular}{llc}
\hline Year & Locality & $\begin{array}{c}\text { No. of traps/size of } \\
\text { the field (ha) }\end{array}$ \\
\hline \multirow{2}{*}{2009} & Bački Petrovac I & $2 / 1$ \\
& Bački Petrovac II & $2 / 1$ \\
& Čenej & $2 / 1$ \\
\hline \multirow{2}{*}{2010} & Bački Petrovac I & $3 / 1.5$ \\
& Bački Petrovac II & $3 / 1.5$ \\
\multirow{2}{*}{2011} & Kisač & $3 / 1.5$ \\
\hline \multirow{2}{*}{} & Bački Petrovac & $1 / 0.5$ \\
& Kisač & $1 / 0.5$ \\
\hline
\end{tabular}

their flight activity with the special reference to the species found to be the most abundant and important. This analysis provides first and unique insight into the aphidophauna of oilseed pumpkin crops in Serbia by the comparison of aphid flight data, plant growth stage and presence of virus species in oilseed pumpkin crops in Serbia.

\section{Materials and Methods}

Aphid populations were monitored during a three-year period (2009-2011) at six localities (eight cucurbit crops) in the Vojvodina Province, north-western part of Serbia, which is the main growing area of C. pepo 'Olinka', domestic oilseed pumpkin variety (Table 1 ). Monitoring of aphid flight activities was performed using yellow water traps $(22 \times 22 \times 21 \mathrm{~cm})$ with holes under the upper edge. Traps were filed with water approximately to one-third of the volume with addition of liquid detergent. Yellow water traps were placed immediately after the sowing and were positioned at least $15 \mathrm{~m}$ apart from each other, as well as, from the margins of the field. At the beginning of growing season, traps were on the ground, while during the crop growth they were elevated gradually to obtain better visibility for insects. Winged aphid species were captured landing on the oilseed pumpkin plants during the growing season, from May 25 to July 17. Number of traps in each field depended on the size of the field (Table 1). Samples of the insects caught in the traps were collected weekly. The liquid from the traps was sieved and the collected insects were packed into marked glass jars with $70 \%$ alcohol. In the laboratory, after separation from other insects, aphids were conserved in $75 \%$ alcohol. Identification of all collected aphids was carried out using a stereomicroscope and keys for identification of alatae aphids (Taylor, 1984; Jacky \& Bouchery, 1988; Remaudiere $\&$ Seco Fernandez, 1990).

Biodiversity analysis was performed using ShannonWeaver diversity index, the quantitative measurement which takes into account numbers of individuals and species and proportion of each species within the dataset (Krebs, 1989). In the case of this study, dataset is a single trap at certain location examined once a week. ShannonWeaver index reflects the number of different species in a dataset, and how evenly individuals are distributed among determined species. This index ranges between 0 (indicating low community complexity) and 4 (indicating high community complexity).

\section{Results and Discussion}

During the three-year period, 1,447 specimens were collected in 17 yellow water traps which were placed in eight oilseed pumpkin fields at six localities in the Vojvodina Province. Since number of traps was different in different fields, absolute values of collected data were transformed into relative values in order to enable comparison among them. A total of 57 different 
aphid taxa were identified of which 37 taxa were identified to the species level, 17 to genera level, two taxa were determined to family (Aphididae and Pemphigidae), and one to subfamily level (Myzocalidinae). Taxa determined to genus and species level are summarized in Table 2. A total of 37 aphid genera were identified, which are classified into seven subfamilies. This is the first study of aphid species visiting on oilseed pumpkin plants in Serbia using the yellow water trap method. Until now, only two species that are developing colonies on Cucurbita pepo in our country have been known, and they are $A$. gossypii and M. euphorbiae (Petrović-Obradović, 2003).

The highest total number of aphids were caught in 2009 (755), followed by 489 aphids in 2011. A much lower number of aphids (203 specimens) were recorded in 2010 compared with the other two years. The highest number of collected aphid species (maximum population density) in yellow traps was in Bački Petrovac locality in 2011, representing 28.3\% of all collected species. In 2011 in the Vojvodina Province, the average estimated disease incidence was high, over 60\%, ZYMV was the most prevalent virus, while CMV and WMV were also detected but in slightly lower percentage, and the number of mixed, including triple infections, was higher than the number of single infections (Vučurović, 2013). The most abundant species identified in 2011 were $A$. pisum and $A$. fabae. In addition to early infection by aphids, the frequent occurrence of mixed infection could be explanations of high disease incidence.

The lowest number of collected aphid species, 29 individuals representing $2 \%$ of total collected aphids, was recorded in the Kisač locality in 2010. The crop at this locality was surrounded by corn crops on each four sides, indirectly pointing very important role of surrounding crops as insulating belt which could prevent or postpone virus infection by avoiding peak of aphid flight activity.

During this study, aphid flight activities in oil seed pumpkin was studied by yellow water traps, a sampling tool used to obtain data on aphid diversity, abundance of each species and dynamics of each species' flight in alfalfa, potato, beans and cabbage (Mora-Aguilera, 1995; Vučetić et al., 2013a; Vučetić et al., 2013b; Jovičić et al., 2017). This method proved to be suitable and reliable for estimating species composition of winged aphids landing in oilseed pumpkin crops.

In 2009, the highest number of different taxa was in early June, 17 out of a total of 30 and 22 out of 29 , in the locality of Bački Petrovac and Čenej, respectively. The most abundant species identified were $M$. persicae, $A$. pisum, $A$. corni and $A$. gossypii. All of them, except $A$. corni, are known as vectors of cucurbits viruses (Mora-Aguilera, 1995). In the locality Bački Petrovac the most frequent species was $M$. persicae, while in the Čenej locality it was $A$. pisum. Maximum population density of these two species was recorded in the first half of June.

In 2010, the highest number of different taxa was in early June in crops Bački Petrovac I (16 out of a total 21) and Bački Petrovac II (10 out of 26), while in the Kisač locality the highest number of taxa (5 out of 10) was in early to mid-June. The most abundant species were $A$. pisum and $A$. fabae, both of them are known vectors of ZYMV, WMV and CMV (Raccah et al., 1985; MoraAguilera, 1995; Gildow et al., 2008). Maximum population density of these two species was recorded in early June.

In 2011, in the Kisač locality the highest number of different taxa (9 out of a total 14) was at the beginning of June, while in the Bački Petrovac locality was in early July (22 out of 28). The most abundant species were $A$. fabae, A. corni, A. pisum, A. craccivora and A. gossypii. All species except $A$. corni are well known vectors of ZYMV, WMV and CMV (Raccah et al., 1985; Mora-Aguilera, 1995; Gildow et al., 2008). Maximum population density of the first two species was recorded in early July, while the maximum population density of $A$. pisum, $A$. craccivora and A. gossypii was reached during the first weeks of June.

In general, in all three years of investigation $A$. fabae (15\%), M. persicae (13.4\%) and A. pisum (11.7\%) were predominant, followed by $A$. corni $(6.4 \%)$ and $A$. gossypii $(5.6 \%)$. All of them, except $A$. corni, are reported as efficient vectors of cucurbit viruses. In total, these five species were representing $52.1 \%$ of all aphids collected during this research. All five species were found in each locality, except $M$. persicae which was not found in Kisač locality in 2010. Based on the abundance and population dynamics of aphis species, the natural spread of aphidtransmitted cucurbit viruses is often accomplished by $A$. pisum, A. craccivora, A. gossypii and M. persicae (Eastop, 1977; Katis et al., 2006). However, investigation that was carried out in watermelon crops in Croatia showed that Toxoptera aurantii, A. gossypii and Hyperomyzus lactucae were predominant (Čuljak et al., 2005). Similarly, investigation carried out in Florida showed that the most abundant species in watermelon crops were: Uroleucon pseudambrosiae Tetraneura nigriabdominalis, Aphis middletonii, A. gossypii, $M$. persicae, A. spiraecola, Lipaphis erysimi and $A$. craccivora, all of them are known vectors of at least one of cucurbit viruses except T. nigriabdominalis (Mora-Aguilera, 1995).

Three of five economically the most important cucurbit viruses ZYMV, WMV and CMV are present and widespread in Serbia (Vučurović et al., 2012). These viruses are transmitted in non-persistent manner by a number of different aphid species: 80 species are reported as CMV vectors, 42 species are vectors of WMV while 26 species transmit ZYMV (Palukaitis et al., 1992; Kucharek \& Purcifull, 1997; Katis et al., 2006). Two species, among the five most frequent aphid species in oilseed pumpkin crops in Serbia, $M$. persicae and $A$. gossypii, are considered as the most efficient vector species of ZVMV, WMV and CMV (Castle et al., 1992; Lecoq et al., 1992; Palukaitis et al., 1992; Desbiez \& Lecoq, 1997; Provvidenti, 2000; Katis et al., 2006). During this investigation out of 57 taxa found in oilseed pumpkin crops, 17 are konwn as vectors of ZYMV, 18 of WMV and 15 of CMV. In total 25 out of a total of 57 taxa are known as vectors of at least one of three viruses present in Serbia (ZYMV, WMV or CMV) (Table 2). It is very 
Table 2. Aphid taxa identified in oilseed pumpkin crops in Serbia from 2009 to 2011

\begin{tabular}{|c|c|c|c|c|c|c|c|c|c|}
\hline \multirow{2}{*}{ Subfamily } & \multirow{2}{*}{ Genus } & \multirow{2}{*}{ Species } & \multicolumn{4}{|c|}{ Number of individuals } & \multicolumn{3}{|c|}{ Virus transmission } \\
\hline & & & 2009 & 2010 & 2011 & Total & ZYMV & WMV & CMV \\
\hline Anoecinae & Anoecia & corni & 59 & 5 & 28 & 92 & /* & I & I \\
\hline \multirow{42}{*}{ Aphidinae } & \multirow{6}{*}{ Aphis } & craccivora & 43 & 13 & 23 & 79 & $+* *$ & + & + \\
\hline & & fabae & 45 & 25 & 153 & 223 & + & + & + \\
\hline & & gossypii & 53 & 8 & 20 & 81 & + & + & + \\
\hline & & pomi/spiraecola & 21 & 4 & 8 & 33 & + & + & + \\
\hline & & sambuci & 0 & 0 & 1 & 1 & / & + & / \\
\hline & & spp. & 140 & 74 & 51 & 265 & / & / & / \\
\hline & Hyalopterus & pruni & 4 & 6 & 4 & 14 & + & + & / \\
\hline & Protaphis & spp. & 2 & 0 & 0 & 2 & / & / & / \\
\hline & \multirow{3}{*}{ Rhopalosiphum } & padi & 6 & 2 & 11 & 19 & / & + & + \\
\hline & & nymphaeae & 0 & 1 & 0 & 1 & / & / & / \\
\hline & & maidis & 3 & 2 & 0 & 5 & + & + & + \\
\hline & Schizaphis & graminum & 10 & 0 & 1 & 11 & / & / & / \\
\hline & Acyrthosiphon & pisum & 96 & 49 & 24 & 169 & + & + & + \\
\hline & \multirow{2}{*}{ Amphorophora } & rubi & 0 & 1 & 0 & 1 & / & / & / \\
\hline & & spp. & 3 & 2 & 4 & 9 & / & / & / \\
\hline & \multirow{2}{*}{ Aulacortbum } & solani & 7 & 0 & 0 & 7 & + & + & / \\
\hline & & cardui & 1 & 0 & 0 & 1 & + & + & I \\
\hline & \multirow[t]{2}{*}{ Bracbycaudus } & belichrysi & 2 & 6 & 0 & 8 & / & / & + \\
\hline & & spp. & 0 & 0 & 1 & 1 & / & / & / \\
\hline & Brevicoryne & brassicae & 12 & 3 & 2 & 17 & + & & + \\
\hline & \multirow{3}{*}{ Capitophorus } & eleagni & 16 & 0 & 0 & 16 & / & / & / \\
\hline & & horni & 0 & 1 & 0 & 1 & / & / & / \\
\hline & & spp. & 11 & 2 & 9 & 22 & / & / & / \\
\hline & \multirow[t]{2}{*}{ Cavariella } & spp. & 0 & 1 & 0 & 1 & / & / & / \\
\hline & & galeopsidis & 0 & 0 & 1 & 1 & / & / & / \\
\hline & \multirow[t]{2}{*}{ Cryptomyzus } & ribis & 1 & 0 & 1 & 2 & / & + & / \\
\hline & & spp. & 1 & 0 & 0 & 1 & / & / & I \\
\hline & Diuraphis & noxia & 10 & 0 & 0 & 10 & / & / & / \\
\hline & Dysaphis & spp. & 9 & 3 & 0 & 12 & / & + & / \\
\hline & Hyadaphis & polonica & 12 & 6 & 4 & 22 & / & / & / \\
\hline & Hyperomyzus & lactucae & 3 & 0 & 0 & 3 & + & + & + \\
\hline & Lipaphis & erysimi & 0 & 0 & 3 & 3 & + & / & + \\
\hline & \multirow{2}{*}{ Macrosipbum } & euphorbiae & 0 & 0 & 7 & 7 & + & + & + \\
\hline & & rosae & 1 & 1 & 1 & 3 & + & / & / \\
\hline & Metopolophium & dirhodum & 5 & 0 & 13 & 18 & + & / & + \\
\hline & Myrodium & modestum & 1 & 0 & 0 & 1 & / & / & / \\
\hline & \multirow{2}{*}{ Myzus } & cerasi & 2 & 1 & 0 & 3 & + & + & / \\
\hline & & persicae & 126 & 2 & 65 & 193 & + & + & + \\
\hline & Phorodon & bumuli & 0 & 1 & 0 & 1 & / & + & l \\
\hline & Rhopalomyzus & spp. & 1 & 0 & 0 & 1 & / & / & / \\
\hline & Sitobion & avenae & 8 & 2 & 2 & 12 & / & / & + \\
\hline & Trichosiphonaphis & polygonifoliae & 1 & 1 & 2 & 4 & l & / & I \\
\hline & Sithe & maydis & 1 & 0 & 0 & 1 & / & / & I \\
\hline Chaitophorinae & Sтріла & spp. & 1 & 0 & 0 & 1 & / & / & / \\
\hline & Chaitophorus & spp. & 2 & 0 & 1 & 3 & l & / & / \\
\hline Lachninae & Cinara & spp. & 2 & 0 & 0 & 2 & 1 & 1 & / \\
\hline Lachninae & Eulachnus & spp. & 0 & 0 & 1 & 1 & / & / & / \\
\hline & Euceraphis & spp. & 0 & 2 & 0 & 2 & / & / & / \\
\hline Myzocallidinae & Therioaphis & trifolii & 3 & 0 & 0 & 3 & / & / & + \\
\hline & Tinocallis & spp. & 1 & 0 & 0 & 1 & / & / & 1 \\
\hline Pemnhioinze & Tetraneura & spp. & 4 & 8 & 3 & 15 & / & / & I \\
\hline rempningine & Pemphigus & spp. & 4 & 1 & 0 & 5 & I & / & I \\
\hline Phyllaphidinae & Phyllaphis & fagi & 2 & 3 & 0 & 5 & / & / & / \\
\hline
\end{tabular}


important to poin out that out of 1,447 specimens collected during three years of investigation 917 (63.4\%) are vectors of at least one of three viruses (Table 2) (Raccah et al., 1985; Mora-Aguilera, 1995; Gildow et al., 2008). A. corni was detected in the considerably high abundance during three year period and since it is unknown as vector of cucurbit viruses, it is of a great importance to determine the transmissibility of ZYMV, WMV and CMV by this aphid species.

Most trapped aphid species, are non-colonizers on oilseed pumpkin, migrated from nearby crops and weeds. During all three years of investigation oilseed pumpkin individual plants were frequently colonized by A. gossypii, which is in accordance with data observed by Perring et al. (1992) and Webb (2007). In Serbia, the maximum aphid flight activities and at the same time the maximum vector activities occur at the end of May-early June (Petrović-Obradović, 2003). In that period, oilseed pumpkin is at early stages of growth and very susceptible to virus infection.
Examination of traps from same localities in different years showed differences in composition and number of aphids. In consent obtained values of total Shannon-Weaver index varied constantly ranging from 1.8 to 2.8 (Figure 1). The highest value of ShannonWeaver (2.8) was recorded in first year of research in Bački Petrovac I locality, while the lowest maximal Shannon-Weaver (1.8) was recorded in Kisač locality in 2010. Values over two of Shanon-Weaver index placed most localities in group of medium to rich localities in aphidofauna (McDonald, 2003).

Maximal Shannon-Weaver index also differed upon year of investigation and locality, ranging from 0.7 to 2.6 (Figure 2). The highest value of maximal ShannonWeaver (2.6) was recorded in first year of research in Čenej, while the lowest maximal Shannon-Weaver (0.7) was recorded in Kisač locality in 2010. Considering different weeks of investigation, crops, years and localities Shanon-Weaver diversity index differed significantly from 0 to 2.6 (Figure 3-6). Different values of Shanon-Weaver

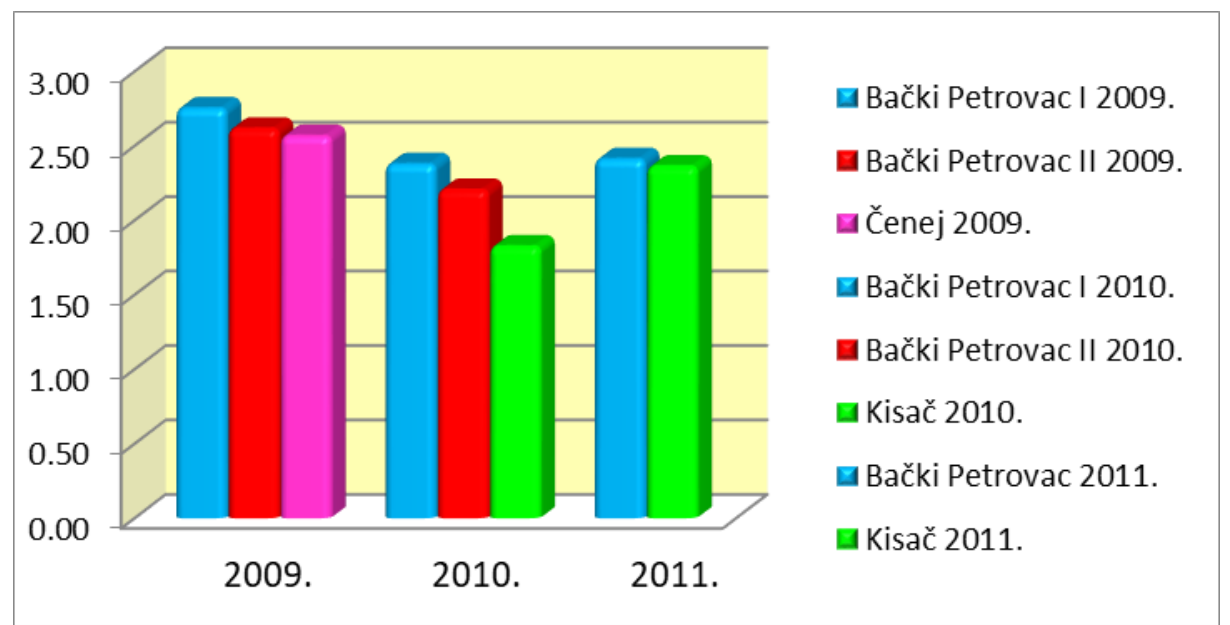

Figure 1. Total Shannon-Weaver diversity index by year for all inspected crops

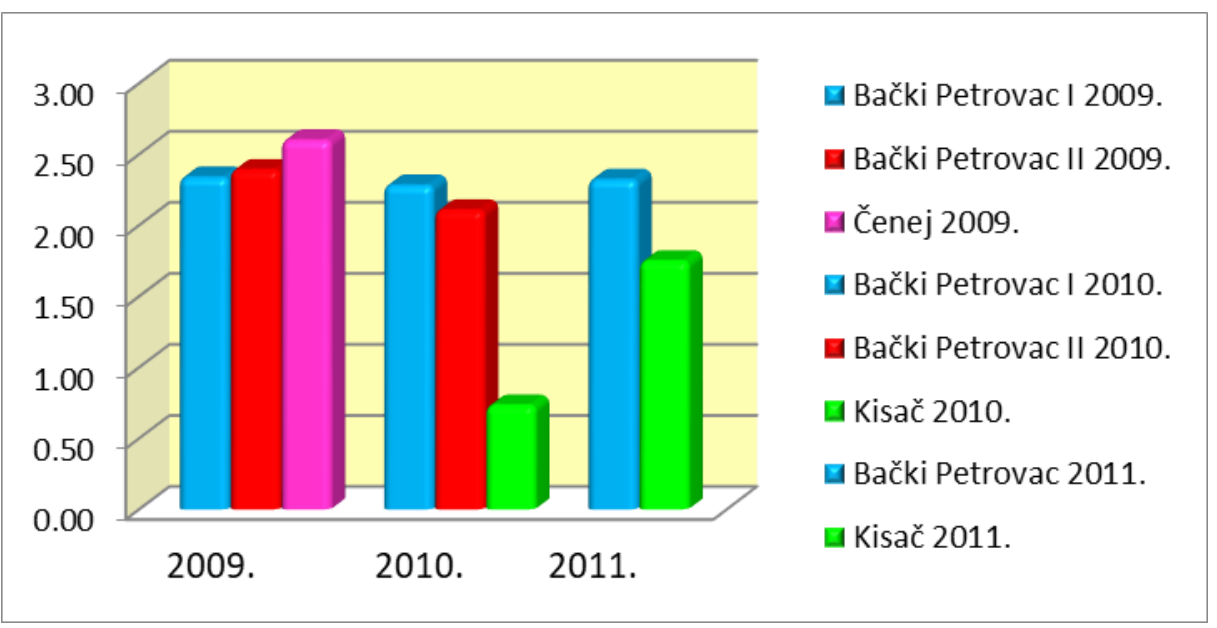

Figure 2. Maximal Shannon-Weaver diversity index by year for all inspected crops 


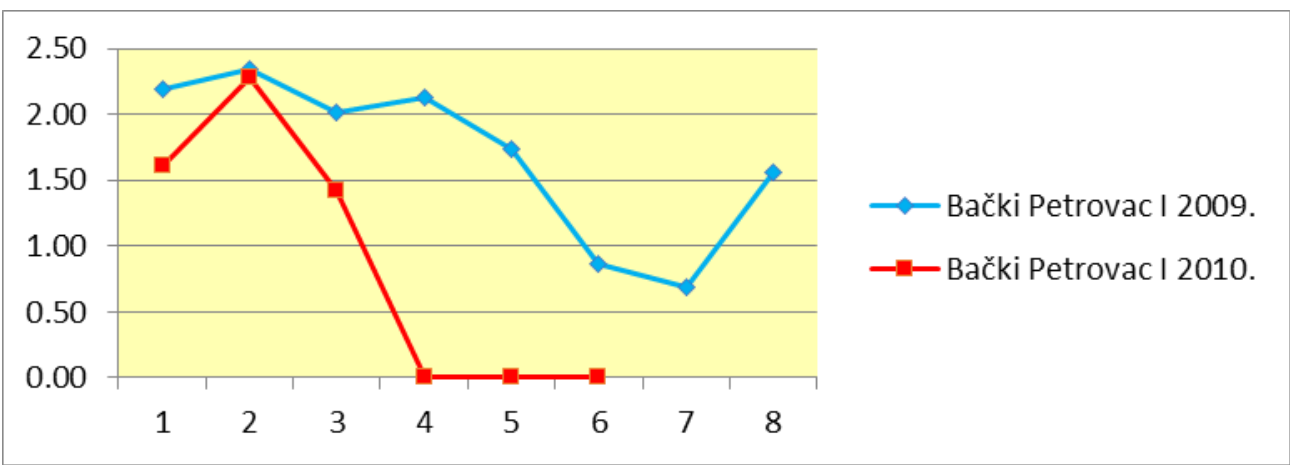

Figure 3. Shannon-Weave diversity indexes through weeks during 2009 and 2010 on the locality Bački Petrovac, crops Bački Petrovac I 2009 and Bački Petrovac I 2010

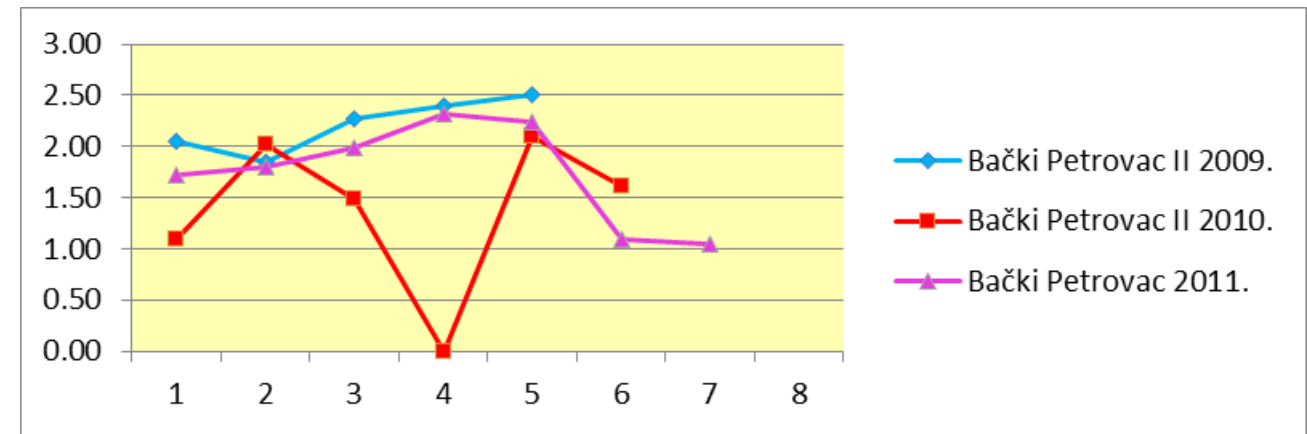

Figure 4. Shannon-Weave diversity indexes through weeks during 2009, 2010 and 2011 on the locality Bački Petrovac, crops Bački Petrovac II 2009, Bački Petrovac II 2010 and Bački Petrovac 2011

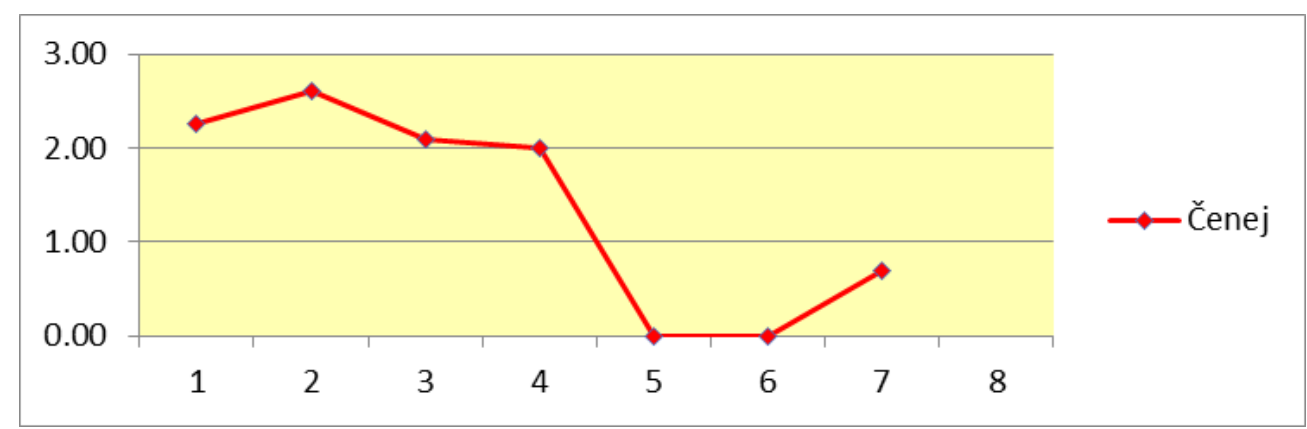

Figure 5. Shannon-Weave diversity index through weeks during 2009 on the locality Čenej

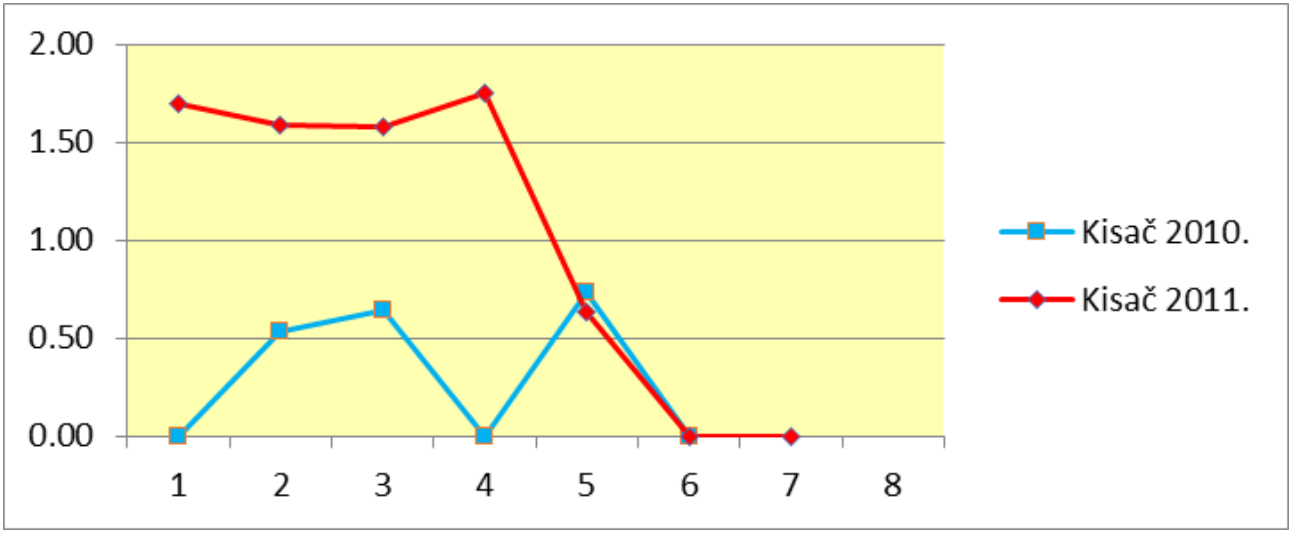

Figure 6. Shannon-Weave diversity index through weeks during 2010 and 2011 on the locality Kisač, crops Kisač 2010 and Kisač 2011 
index from year to year for the same locality as was recorded in this study could be due to differences in weather conditions (Morgan, 2000). It is very important to notice that Shanon-Weaver diversity index in almost all crops reached its highest value in the second week of investigation or in early stages of oilseed pumpkin growth when plant had 5-6 true leaves or in flowering stage. Those data are very important because if virus infection would occur in those stages it could cause substantial damage to yield and fruit and seed quality. Cucurbit viruses can cause considerable crop losses when plants are infected during the early growth stages (Blua \& Perring, 1989; Lecoq et al., 1992; Walkey et al., 1992; Desbiez \& Lecoq, 1997; Fletcher et al., 2000). Early infection with ZYMV which is considered as the most damaging cucurbit virus could lead to total yield losses (Lecoq et al., 1981; McLeod et al., 1986; Blua and Perring, 1989; Al-Shahwan et al., 1995).

Further investigations are needed, especially on the transmissibility of ZYMV, CMV and WMV by their aphid vectors present in cucurbit crops in Serbia and determination of aphid species which play a major role in primary, as well as secondary viral dispersal.

\section{Conclusions}

Over the last decades cucurbits production is significantly increased in Serbia, especially oilseed pumpkin production. The most important limiting factor in cucurbit production are viruses which are transmitted in non-persistent manner by different aphid species. Aphid transmitted viruses in cucurbits have been well studied in Serbia and among five viruses present, the most important are Zucchini yellow mosaic virus (ZYMV), Watermelon mosaic virus (WMV) and Cucumber mosaic virus (CMV). On the other hand, the fauna of aphids appearing on cucurbits, including oilseed pumpkin have been poorly investigated in Serbia. This is the first study of aphid species visiting oilseed pumpkin plants in Serbia using the yellow water trap method. A total of 57 different aphid taxa were identified of which 37 taxa were identified to the species level, 17 to genera level, two taxa were determined to family, and one to subfamily level. In general, the most abundant aphid species caught during this investigation were Aphis fabae, Myzus persicae, Acyrthosiphon pisum, Anoecia corni and Aphis gossypii. The only species found to colonize oilseed pumpkin is $A$. gossypii. Most trapped aphid species are non-colonizers on oilseed pumpkin and are known as vectors of cucurbit viruses. In total $63.4 \%$ of all trapped species are vectors of at least one of three viruses ZYMV, WMV or CMV. Shanon-Weaver diversity index in almost all crops would reach its highest value in second week of investigation or in early stages of oilseed pumpkin growth when plant had 5-6 true leaves or in flowering stage. In Serbia, the maximum aphid flight activities and at the same time the maximum vector activities occur at the end of May-early June. In that period, oilseed pumpkin is at early stages of growth and very susceptible to virus infection.

\section{References}

Al-Shahwan, I. M., Abdalla, O. A. \& Al-Saleh, M. A. (1995) Response of greenhouse-grown cucumber cultivars to an isolate of Zucchini yellow mosaic virus (ZYMV). Plant Disease, 79(9), 898-901.

Bananej, K., Keshavaraz, T., Vahdat, A., Hosseini Salkdeh, G. \& Glasa, M. (2008). Biological and molecular variability of Zucchini yellow mosaic virus in Iran. Journal of Phytopathology, 156 (11-12), 654-659. doi: 10.1111/j.1439-0434.2008.01430.x

Berenji, J. (2010). Uljana tikva i njena prizuodnja. Novi Sad: Institut za ratarstvo i povrtarstvo.

Berenji, J., Sabadoš, V. \& Ivan, J. (2004). Uljana tikva korisna i unosna kultura. Novi Sad: Tamnograf.

Blackman, R. L. \& Eastop, V. F. (2006). Aphids on the World's Herbaceous Plants and Shrubs. West Sussex: John Wiley \& Sons Ltd.

Blua, M. J., \& Perring, T. M. (1989). Effect of Zucchini yellow mosaic virus on development and yield of cantaloupe (Cucumis melo). Plant Disease, 73(4), 317-320.

Castle, S. J., Perring, T. M., Farrar, C. A. \& Kishaba, A. N. (1992). Field and laboratory transmission of Watermelon mosaic virus 2 and Zucchini yellow mosaic virus by various aphid species. Phytopathology, 82(2), 235-240.

Čuljak, G. T., Barčić, I. J., Bažok, D. \& Grubišić, D. (2005). Aphid fauna (Hemiptera: Aphidoidea) in Croatia. Entomologia Croatica, 9(1/2), 57-69.

Desbiez, C. \& Lecoq, H. (1997). Zucchini yellow mosaic virus. Plant Pathology, 46(6), 809-829. doi:10.1046/j.1365-3059.1997.d01-87.x

Easop, V. Y. (1977). Worldwide importance of aphids as virus vectors. In: K.F. Harris \& K. Maramorosch (ed.), Aphids as Virus Vectors, pp. 3-61. New York: Academic Press.

Fletcher, J. D., Wallace, A. R. \& Rogers, B. T. (2000). Potyvirus in New Zealand buttercup squash (Cucurbita maxima Duch.): yield and quality effects of ZYMV and WMV2 virus infections. Nem Zealand Journal of Crop and Horticultural Science, 28(1), 17-26. doi.org/10.1080/01140671.2000.9514118

FAO (2014). Food and Agriculture Organization of the United Nations FAOSTAT ProdSTAT, Production Crops. Available at: http:// faostat.fao.org/site/567/default. aspx\#ancor

Gildow, F. E., Shah, D. A., Sackett, W. M., Butzler, T., Nault, B. A. \& Fleischer, S. J. (2008). Transmission efficiency of Cucumber mosaic virus by aphids associated with virus epidemics in snap bean. Phytopathology, 98(11), 1233-1241. doi.org/10.1094/ PHYTO-98-11-1233.

Hily, J. M., García, A., Moreno, A., Plaza, M., Wilkinson, M. D., Fereres, A., Fraile, A. \& García-Arenal, F. (2014). The relationship between host lifespan and pathogen reservoir potential: an analysis in the system Arabidopsis thalianacucumber mosaic virus. PLoS Pathogens, 10(11), e1004492. doi.org/10.1371/journal.ppat.1004492

Jacky, F. \& Bouchery, Y. (1988). Atlas des formes ailes des especes courantes de pucerons. Colmar: INRA.

Jovičić, I., Radonjić, A. \& Petrović-Obradović, O. (2017). Flight activity of aphids as potential vectors of viral infection of alfalfa in Serbia. Pesticides \& fitomedicine, 32(3-4), 173-179. doi.org/10.2298/PIF1704173J

Katis, N. I., Tsitsipis, J. A., Lykouressis, D. P., Papapanayotou, A. Kokinis, G. M., Perdikis, D. C. \& Manoussopoulos, I. N. (2006). Transmission of Zucchini yellow mosaic virus by colonizing and non-colonizing aphids in Greece and new aphid vectors of the virus. Journal of Phytopathology, 154(5), 293-302. doi.org/10.1111/ j.1439-0434.2006.01096.x

Krebs, C. (1989). Ecological Methodology. New York: Harper \& Collins.

Kucharek, T. A. \& Purcifull, D. E. (1997). Aphid-transmitted viruses of cucurbits in Florida. Florida Cooperative Extension Service Circular, No. 1184. Gainesville: University of Florida.

Lecoq, H. (1992). Les virus des cultures de melon et de courgette de plein champ (I). PHM Revue Horticole, 324, 15-25.

Lecoq, H., Desbiez, S., Wipf-Schibel, C. \& Girard, M. (2003). Potential involvement of melon fruit in long distance dissemination of cucurbit potyviruses. Plant Disease, 87(8), 955 959. doi.org/10.1094/PDIS.2003.87.8.955 
Lecoq, H., Pitrat, M. \& Clement, M. (1981). Identification et caracterisation d'un potyvims provoquant la maladie du rabougn.ssement jaune du melon. Agronomie, 1, 827-834.

Luis-Arteaga, M., Alvarez, J. M., Alonso-Prados, J. L., Bernal, J. J., GarcíaArenal, F., Laviña, A., Batlle, A. \& Moriones, E. (1998). Occurrence, distribution, and relative incidence of mosaic viruses infecting fieldgrown melon in Spain. Plant Disease, 82(9), 979-982.

McDonald, G. (2003). Biogeography: Space, Time and Life. New York: John Wiley and Sons.

Mcleod, P. J., Scott, H. A. \& Morelock, T. E. (1986). Zucchini yellow mosaic virus: a new severe cucurbit disease. Arkansas Farm Research 35. Agricultural Experiment Station, Division of Agriculture. Fayetteville: University of Arkansas.

Mora-Aguilera, G. (1995). Aphid vector dynamics and temporal and spatial characterization of watermelon virus epidemics. Gainesville: University of Florida, pp 1-198, Doctoral dissertation.

Morgan, D. (2000). Population dynamics of the bird cherry-oat aphid, Rhopalosiphum padi (L.), during the autumn and winter: a modelling approach. Agricultural and Forest Entomology (2), 297-304. doi.org/10.1046/j.1461-9563.2000.00079.x

Palukaitis P., García-Arenal, F. (2003). Cucumoviruses. Advances in Virus Research, 62, 241-323.

Palukaitis, P., Roossinck, M. J., Dietzgen, R. G. \& Francki, R. I. B. (1992). Cucumber mosaic virus. Advances in Virus Research, 41, 281-348.

Perring, T. M., Farrar, C. A., Mayberry, K. \& Blua, M. J. (1992). Research reveals pattern of cucurbit virus spread. California Agriculture, 46, 3540.

Petrović-Obradović, O. (2003). Aphid fauna (Homoptera: Aphididae) in Serbia. Belgrade: University of Belgrade - Faculty of Agriculture (in Serbian).

Provvidenti, R. (2000). APSnet Feature story: Zucchini yellow mosaic (pp. 3). New York: Experiment Station Cornell University Geneva. http:// www.apsnet.org/online/feature/pumpkin/zuccyell.html

Provvidenti, R. \& Schroeder, W.T. (1970). Epiphitotic of watermelon mosaic among Cucurbitaceae in Central New York in 1969. Plant Disease Reporter, 54, 744-748.

Raccah, B., Gal-On, A., \& Eastop, V. F. (1985). The role of flying aphid vectors in the transmission of cucumber mosaic virus and potato virus $Y$ to peppers in Israel. Annals of applied Biology, 106(3), 451-460.
Remaudiére, G. \& Seco Fernandes, V. (1990). Cles pour aidé à la reconnaissance des ailes de pucerons pieges en region Mediterraneenne (Hom. Aphoidea). Universidad de Leon, Leon, I-II, pp. 205.

RZS (2014). Statistički godišnjak biljne proizvodnje. Republika Srbija Republički zavod za statistiku. Available at: http:// webrzs.stat.gov.rs/WebSite/Public/Report View.aspx

Schaffer, A. A. \& Paris, H. S. (2003). Melons, Squashes, and Gourds. In: L. Trugo and M. Finglas (ed.), Encyclopedia of Food Sciences and Nutrition (Second Edition), pp. 3817-3826. San Diego: Academic Press.

Sevik, M. A. \& Arli-Sokmen, M. (2003). Viruses infecting cucurbits in Samsun, Turkey. Plant Disease, 87(4), 341-344. doi.org/10.1094/ PDIS.2003.87.4.341

Taylor, L. R. (1984). A Handbook for Aphid Identification. Harpenden: Rothamsted Experimental Station.

Vučetić, A., Jovičić, I. \& Petrović-Obradović, O. (2013a). The pressure of aphids (Aphididae, Hemiptera), vectors of potato viruses. Archives of Biological Sciences, 65(2), 659-666. doi:10.2298/abs1302659v

Vučetić, A., Vukov, T., Jovičić, I., \& Petrović-Obradović, O. (2013b). Monitoring of aphid flight activities in seed potato crops in Serbia. ZooKeys, (319), 333. doi.org/ 10.3897/zookeys.319.4315

Vučurović, A. (2013). Diversity, biological and molecular characterization of cucurbit viruses and disease epidemiology in Serbia. Belgrade: University of Belgrade-Faculty of Agriculture, pp. 220 (in Serbian), Doctoral Dissertation.

Vučurović, A., Bulaiić, A., Stanković, I., Ristić, D., Berenji, J., Jović, J. \& Krstić, B. (2011). First report of the occurrence of Cucurbit aphidborne yellows virus on oilseed pumpkin in Serbia. Plant Disease, 95 (8), 1035. doi.org/10.1094/PDIS-02-11-0147

Vučurović, A., Bulajić, A., Stanković, I., Ristić, D., Berenji, J., Jović, J. \& Krstić, B. (2012). Non-persistently aphid-borne viruses infecting pumpkin and squash in Serbia and partial characterization of Zucchini yellow mosaic virus isolates. European Journal of Plant Pathology, 133(4), 935-947. doi.org/10.1007/s10658-012-9964-x.

Walkey, D. G. A. (1992). Zucchini Yellow Mosaic Virus: Control by mild strain protection. Phytoparasitica, 20(Suppl), 99-103. doi.org/10.1016/0261-2194(95)00030-5

Webb, S. E. (2007). IPM case studies: Cucurbits. In: H. F. van Emden \& R. Harrington (ed.), Aphids as Crop Pests (pp. 639-649). Wallingford: CABI.

\section{Diverzitet i praćenje leta lisnih vaši kao potencijalnih vektora virusa uljane tikve u Srbiji}

\section{Ana Vučurović · Olivera Petrović-Obradović · Anđa Radonjić · Dušan Nikolić · Katarina Zečević · Ivana Stanković · Branka Krstić}

Sažetak: Afidofauna koja se javlja na tikvama, uključujući uljanu tikvu do sada nije dobro ispitana u Srbiji. Da bi utvrdili diverzitet lisnih vaši koje posećuju useve tikava u Srbiji, kao i da bi pratili aktivnost i dinamiku njihovog leta, koristili smo žute lovne klopke. Tokom perioda od 2009. do 2011. godine ukupno je sakupljeno 1447 jedinki i determinisano 57 taksona lisnih vaši. Tokom 2009. godine, uhvaćen je najveći broj jedinki (755), dok je tokom 2010. i 2011. godine uhvaćeno 203, odnosno 489 jedinki lisnih vaši. Najzastupljenije vrste bile su Aphis fabae (15\%), Myzus persicae (13,4\%) i Acyrthosiphon pisum (11,7\%), a zatim Anoecia corni (6,4\%) i Aphis gossypii (5,6\%). Za sve vrste, osim za A. corni, potvrđeno je da su vektori virusa tikava. Ovih pet najzastupljenijih vrsta predstavljaju 52,1\% od svih sakupljenih jedinki vaši u toku ovih istraživanja. Od ukupno 57 taksona nađenih u usevima uljane tikve, 17 su poznati vektori ZYMV, 18 WMV i 15 CMV. Ukupno posmatrano, 25 od 57 nađenih taksona su vektori bar jednog od tri virusa tikava prisutnih u Srbiji. Od ukupno 1447 jedinki sakupljenih tokom tri godine istraživanja, $917(63,4 \%)$ su vektori bar jednog od tri virusa tikava. Kolonizacija pojedinačnih biljaka uljane tikve vrstom $A$. gossypii uočavana je često tokom sve tri godine istraživanja. Rezultati ovih istraživanja, na osnovu ukupnog Shannon-Weaver-ovog indeksa diverziteta koji je varirao između 1,8 i 2,8, ukazuju da se lokaliteti na kojima se gaji uljana tikva u Srbiji svrstavaju u red srednje bogatih do bogatih po sastavu i brojnosti afidofaune. Najveća vrednost Shannon-Weaver-ovog indeksa diverziteta $(2,8)$ zabeležena je tokom 2009. godine na lokalitetu Bački Petrovac I, dok je najniži indeks diverziteta $(1,8)$ zabeležen na lokalitetu Kisač tokom 2010. godine. Shanon-Weaver-ov indeks diverziteta u gotovo svim ispitivanim usevima dostigao je maksimalne vrednosti u drugoj nedelji istraživanja ili u ranim fazama razvoja uljane tikve kada biljke imaju 5-6 pravih listova ili su u fazi cvetanja, što predstavlja najosetljivije faze za ostvarenje infekcije virusima koje mogu da dovedu do značajnih gubitaka u prinosu.

Ključne reči: diverzitet lisnih vaši, dinamika leta lisnih vaši, Shannon-Weaver indeks diverziteta, uljana tikva, žute lovne klopke, vektori virusa 